\title{
Review
}

\section{ACUTE PHASE PROTEINS IN SHEEP AND GOATS - FUNCTION, REFERENCE RANGES AND ASSESSMENT METHODS: AN OVERVIEW}

\author{
P. T. ILIEV ${ }^{1} \&$ T. M. GEORGIEVA ${ }^{2}$ \\ ${ }^{1}$ Department of Veterinary Microbiology, Infectious and Parasitic Diseases, ${ }^{2}$ Department of \\ Pharmacology, Animal Physiology and Physiological Chemistry, Faculty of Veterinary \\ medicine, Trakia University, Stara Zagora, Bulgaria
}

\section{Summary}

Iliev, P. T. \& T. M. Georgieva, 2018. Acute phase proteins in sheep and goats - function, reference ranges and assessment methods: An overview. Bulg. J. Vet. Med., 21, No 1, 1-16.

Acute phase response (APR) is activated by disorders in systemic homeostasis. The main purpose of APR is to prevent further tissue damage by isolation and destruction of causative agent, removing the toxic products and providing conditions for tissue repair. Probably the most significant change during APR is a transformation in the liver protein spectrum expressed by increased rate of synthesis of acute phase proteins (APPs) or acute phase reactants. Numerous APPs that perform specific functions are established whose quantitative variations vary considerably among different animals. Some of them are mediators (C-reactive protein, fibrinogen), others act as inhibitors (protease inhibitors $-\alpha 1$ antitrypsin) and especially in small ruminants, the most specific APPs are scavengers and transporters (haptoglobin, serum amyloid A). Despite considerable progress, many of the characteristics of APPs in domestic animals are still poorly understood especially in sheep and goats. Little is known about some other proteins such as lipopolysaccharide binding protein, hemopexin, alpha-1 antitrypsin, lactoferrin, transferrin, C-reactive protein, ceruloplasmin, fibrinogen and alpha- 1 acid glycoprotein. The aim of this study is to present information concerning the most important functions of APPs, as well as their ranges in healthy sheep and goats and laboratory assay methods.

Key words: acute phase proteins, sheep, goats

\section{INTRODUCTION}

The acute phase response (APR) or acute phase reaction is a complex early, antigen non-specific, defense systemic reaction appearing before a specific immune response is raised (Petersen et al., 2004). It is activated by trauma, neoplastic growth, bacterial, parasitic and viral infection, burns, surgery, immunological disorders etc. (Gruys et al., 2005; Cray et al., 2009; Eckersall \& Bell, 2010; Tothova et al., 2014). The main purpose of APR is to restore the homeostasis by isolating and destroying the harmful agent and to activate the repair process (Janeway et al., 2001; Ceciliani et al., 2002). The damaged tissue is the primary source that initi- 
Acute phase proteins in sheep and goats - function, reference ranges and assessment methods...

ates APR. The early changes involve activation of cells belonging to the innate immunity - macrophages and monocytes which synthesise pro-inflammatory cytokines such as interleukin-1 (IL-1), interleukin-6 (IL-6), tumour necrosis factor alpha (TNF- $\alpha$ ) and some others (Murata et al., 2004). These mediators are involved in the activation of fibroblasts, leukocytes and endothelial cells. The latter, by producing more cytokines (IL-6, IL-8, IL-11, PGE2, LIF, nitric oxide), increase the permeability of blood vessels, enhance leukocyte migration and induce local changes - swelling, pain, redness and warmth which accompany the inflammatory process (Gruys et al., 2005). The increased concentration of cytokines may induce systemic APR and resultant activation of the hypothalamic-pituitary-adrenal system (increased adrenocorticotropic hormone and glucocorticoids production), reduction of growth hormone secretion and a considerable number of metabolic and biochemical changes (complement cascade and blood coagulation system activation; decreased serum concentration of iron, zinc, calcium, vitamin A, $\alpha$ tocopherol; negative nitrogen balance; changes in the concentration of some plasma proteins) clinically manifested by pyrexia, anorexia, weight loss etc. (Moshage, 1997; Gabay \& Kushner, 1999; Gruys et al., 1999; Pyorala, 2000; Gruys et al., 2005; Jain et al., 2011; Ceciliani et al., 2012; O'Reilly \& Eckersall, 2014; Tothova et al., 2014). Downregulation of APR is controlled by many inflammatory mediators (IL-4, IL-10) and hormones (glucocorticoids) as well as by the production of antagonists to proinflammatory cytokines (Gruys et al., 2005). Usually APR continues for 1-2 days and after this period the affected organism should return to normal function
(Ceciliani et al., 2002). If the acute inflammation becomes chronic, APR is still induced (Baumann \& Gauldie, 1994; Jain et al., 2011).

One of the most important metabolic alterations accompanying APR occurs mainly in the liver but also in other organs. It involves the synthesis of a large group proteins, collectively known as acute phase proteins (Ceciliani et al., 2012). Their expression depends on cytokines' levels, whereas the cytokine activity modulation is regulated by glucocorticoids and growth factors (van Miert, 1995; Ceciliani et al., 2002; Gruys et al., 2005).

\section{ACUTE PHASE PROTEINS}

The acute phase proteins are a large group of plasma proteins which originate mainly from the liver in response to pro-inflammatory cytokines (IL-1, IL-6, TNF- $\alpha$ ). They are released very quickly into the circulation, where each performs a specific activity. During APR the serum of APPs concentrations increase substantially while in healthy animals and humans, APPs are undetectable or in negligible quantities. However, some APPs collectively called "permanent" are continuously secreted and released into the bloodstream while the "induced" ones are present in plasma only during APR. In general, the main function of APPs is to defend the host against pathological damages, assist in the restoration of homeostasis and in the regulation of different stages of inflammation (Petersen et al., 2004; Tothova et al., 2014).

APPs can also be synthesised extrahepatically in some tissues such as testicular tissue, adipose tissue, lung, ovary, uterus, mammary glands, digestive tract (Ceciliani et al., 2012). 
The type and magnitude of APP expression varies between the species. Plasma concentrations of major APPs in healthy animals are very low. During the acute phase of inflammation their levels are greatly enhanced in the first few hours after exposure to the pathogenic factors (Gruys et al., 1999; Ceciliani et al., 2002; Petersen et al., 2004). APPs kinetics depends on the animal species and extent of tissue damage. Serum APPs concentrations generally reach a peak within $24-48$ hours. If a new stimulus does not appear and inflammation ceases, the feedback APPs regulation limits the response within 4 to 7 days after challenge. Chronic inflammation is considered as a series of individual inflammatory stimuli and is characterised by longer and slight increase in the serum concentration of APPs as compared to acute inflammation (Sipe, 1985; Murtaugh, 1994; Heegaard et al., 2000; Jain et al., 2011).

\section{CLASSIFICATION OF ACUTE PHASE PROTEINS}

Despite the uniformity in the development of APR between species, there is a lot of evidence showing that each animal has its own specific APPs set (Pyorala, 2000). The biological functions of some APPs studied in ruminants are summarised in Table 1.

In general terms, these proteins can be classified according to their quantitative variation and function.

A) Depending on the magnitude of the increase or decrease by at least $25 \%$ during APR (Murata et al., 2004; Ceron et al., 2005; Eckersall \& Bell, 2010).

- Positive APPs - haptoglobin, serum amyloid A, C-reactive protein.

- Negative APPs - albumin, transferrin, transthyretin (prealbumin, thyroxinebinding protein).

B) Depending on the magnitude of increase in the concentration of positive

Table 1. Biological function of acute phase proteins (according to Ceciliani et al., 2012; O'Reilly \& Eckersall, 2014; Tothova et al., 2014)

\begin{tabular}{|c|c|c|c|}
\hline Proteins & $\begin{array}{l}\text { Abbre- } \\
\text { viation }\end{array}$ & Biological function & $\begin{array}{l}\text { Classifi- } \\
\text { cation }\end{array}$ \\
\hline Haptoglobin & Hp & Binds free haemoglobin & Positive \\
\hline Serum amyloid A & SAA & Binds cholesterol, opsonin & Positive \\
\hline Ceruloplasmin & $\mathrm{Cp}$ & Copper transport, iIron metabolism & Positive \\
\hline Albumin & Alb & $\begin{array}{l}\text { Amino acids source, transporter, osmotic } \\
\text { pressure }\end{array}$ & Negative \\
\hline C-reactive protein & $\mathrm{CPR}$ & $\begin{array}{l}\text { Complement activation, binding to memb- } \\
\text { rane phosphorylcholine, opsonization }\end{array}$ & Positive \\
\hline Fibrinogen & $\mathrm{Fb}$ & Blood clotting & Positive \\
\hline $\begin{array}{l}\text { Lipopolysaccharide } \\
\text { binding protein }\end{array}$ & LPB & $\begin{array}{l}\text { Binds to bacterial LPS, macrophage cell } \\
\text { activation }\end{array}$ & Positive \\
\hline$\alpha_{1}$-acid glucoprotein & AGP & $\begin{array}{l}\text { Bind drugs, inflammatory mediators and } \\
\text { bacterial derived molecules }\end{array}$ & Positive \\
\hline$\alpha_{1}$-antitrypsin & AAT & Serine protease inhibitor & Positive \\
\hline Transferrin & $\mathrm{TF}$ & Binds iron & Negative \\
\hline Hemopexin & Hрx & Heme binding & Positive \\
\hline Lactoferrin & $\mathrm{LF}$ & Binding and transferring $\mathrm{Fe}^{3+}$ ions & Positive \\
\hline
\end{tabular}


APPs (Eckersall \& Bell, 2010; GomezLaguna et al., 2011; Tothova et al., 2014) (Table 2).

- Major APPs - their concentrations increase 10 to 100 -fold, reaching a peak 24-48 hours after pathological stimulus and decline quickly due to short half - life (Niewold et al., 2003).

- Moderate APPs - their concentrations increase 5 to 10 -fold, reaching a peak 2-3 days after pathological stimulus and decline more slowly than major APPs (Eckersall, 2006a).

- Minor APPs - gradually increase by between $50 \%$ and $100 \%$ of their normal level (Eckersall \& Bell, 2010).

C) Depending on their role during inflammation (Tirziu, 2009; Khan \& Khan, 2010).

- Mediators (C-reactive protein, fibrinogen)

- Modulators (complement proteins, inhibitors to coagulation cascade)

- Inhibitors (protease inhibitors $-\alpha 1$-antitrypsin, $\alpha 2$-macroglobulin)

- Scavengers and transporters (haptoglobin, serum amyloid A, ceruloplas$\min$ )

- Immunomodulators ( $\alpha 1$-acid glycoprotein)

D) Depending on their cytokine induction (Murata et al., 2004; Gruys et al., 2005)

- Type 1 dependent (induced by IL-1 and TNF- $\alpha$ )

- Type 2 dependent (induced by IL-6) The synthesis of type- 1 dependent APPs is synergistically affected also by IL-6, in contrast, the secretion of type-2 APPs is neither induced nor synergistically affected by IL-1, moreover it has a inhibitory effect on their synthesis. The reduction of negative APPs in plasma during inflammation is due to the priority of positive APPs synthesis. Furthermore, some of negative APPs are hormonebinding proteins and their reduction provides more available, biologically active forms of hormones, some of which (glucocorticoids) are very important for induction of APR. Other APPs as transthyretin have also an inhibitory effect on IL-1 production by monocytes and endothelial cells, thus its declining concentration may be regarded as a part of the adaptive mechanisms of APR induction (Ceciliani et al., 2002). Some APPs inhibit protease enzymes synthesised by phagocytes and pathogenic microorganisms and therefore protect tissues from damage e.g. $\alpha 1$-antitrypsin, $\alpha 2$-macroglobulin (Gruys et al., 1999). Other major APPs as haptoglobin, serum amyloid A and $\mathrm{C}$-reactive protein act as scavengers by binding metabolites formed during inflammation (Wagener et al., 2001). Some APPs ( $\alpha 1$-acid glycoprotein) have an antibacterial activity and thus positively influence the immune response (Eckersall, 2006b).

Table 2. APPs in sheep and goats

\begin{tabular}{lll}
\hline & Sheep & Goats \\
\hline Major & Haptoglobin, & Haptoglobin, \\
APPs & SAA & SAA \\
Moderate & AGP & Fibrinogen, \\
APPs & & AGP \\
Minor & Fibrinogen, & Ceruloplas- \\
APPs & Ceruloplasmin & min \\
Negative & Albumin & Albumin \\
APPs & & \\
\hline
\end{tabular}

$\mathrm{SAA}=$ serum amyloid $\mathrm{A} ; \mathrm{AGP}=\alpha_{1}$-acid glucoprotein

ACUTE PHASE PROTEINS IN SMALL RUMINANTS

\section{Haptoglobin}

Haptoglobin ( $\mathrm{Hp}$ ) is considered to be a major APP in sheep and goats (Table 2). 
It refers to a group of transporter (metalbinding) plasma proteins that increase during APR (Pannen \& Robotham, 1995). $\mathrm{Hp}$ is synthesised mainly in the liver, although its coding gene is expressed in other tissues such as lung, skin, spleen, kidney and adipose tissue (D'Armiento et al., 1997; Yang et al., 2003). The synthesis of $\mathrm{Hp}$ is mediated and regulated by the growth hormone, insulin, bacterial endotoxin, prostaglandins, pro-inflammatory cytokines - IL-1, IL-6, tumour necrosis factor (Raynes, 1994).

Hp has several distinctive features. According to Yang et al. (2003) and Kato (2009) the most important one is to bind the free haemoglobin $(\mathrm{Hb})$ in equimolar ratio with very high affinity (Table 1 ). The complex $\mathrm{Hp}-\mathrm{Hb}$ is too large and cannot pass through the glomerulus of the kidney and may only be removed by reticuloendothelial system. It is accomplished by binding to CD163 receptors presented on macrophages and monocytes surface (Schaer et al., 2002). Hp-Hb half-life is up to $50 \mathrm{~min}$ (Ceciliani et al., 2012). The quantity of $\mathrm{Hp}$ does not increase in cases in which red blood cells are destroyed in the spleen or liver but not in the vessels (Jain et al., 2011) and it may decrease during massive erythrolysis (Smith \& Roberts, 1994).

The free $\mathrm{Hb}$ in the bloodstream is toxic and has oxidative activity (Wagner et al., 2001). Hp binds it and thus prevents oxygen radicals formation (stimulated by iron), reduces the oxidative damages associated with haemolysis which defines its role as an antioxidant (Smith \& Roberts, 1994; Murata et al., 2004).

$\mathrm{Hb}$ contains iron which is one of essential elements required for bacterial growth. After the $\mathrm{Hp}-\mathrm{Hb}$ complex is formed, the iron becomes unavailable for bacteria which explains the bacteriostatic effect of Hp (Ceciliani et al., 2012).

It is important to note that Hp may inhibit mast cell proliferation and directly interact the effector cells by binding to CD11/CD18 receptor and also to suppress T-cell proliferation (by inhibition of Th2 response) which expresses its immunomodulatory and anti-inflammatory role (El Ghmati et al., 1996; Murata et al., 2004).

\section{Serum amyloid $A$}

Serum amyloid A (SAA) is also a major APP in small ruminants (Table 2). Its function is not fully understood but some activities have been well described and documented. Several effects of SAA are well explored, e.g. binding, transporting and scavenging of cholesterol from destroyed cells and lipid debris from bacteria to the liver during inflammation ( $\mathrm{Ce}$ ciliani et al., 2012); inhibition of phagocyte oxidative burst (Linke et al., 1991; Gruys et al., 2005), inhibition of platelet aggregation (Petersen et al., 2004), detoxification of endotoxin (binding to lipopolysaccharide) (Schroedl et al., 2001; Murata et al., 2004), binding to Gram negative bacteria and opsonisation (Hari-Dass et al., 2005; Tothova et al., 2011), inhibition of lymphocytes and endothelial cells proliferation (Murata et al., 2004). It exhibits chemotactic recruitment of inflammatory cells to localised areas of inflammation (Xu et al., 1995; Uhlar \& Whitehead, 1999) and down regulates some systemic (pyrexia) events during AP (Shainkin-Kestenbaum et al., 1991; Uhlar \& Whitehead, 1999) (Table 1). SAA is synthesised by IL-1, IL-6 and TNF $\alpha$ mainly from hepatocytes but intestinal epithelial cells, macrophages and smoothmuscle cells can also release it by the same pro-inflammatory cytokines (Vreugdenhil et al., 1999; McDonald et al., 
Acute phase proteins in sheep and goats - function, reference ranges and assessment methods...

2001; Murata et al., 2004). Based on the abovementioned information, it can be concluded that SAA plays a role as an opsonin, prevents accumulation of cholesterol on the site of inflammation and modulates innate immune reactions.

It is established that the normal ovine colostrum contains an isoform of SAA (mammary-associated SAA) which stimulates mucin secretion from the intestine and prevents bacteria development and adapts postparturient period of the newborn animals (McDonald et al., 2001; Mack et al., 2003).

\section{Ceruloplasmin}

Ceruloplasmin (Cp) is a metal-binding APP that stores and transports copper in the body (O'Reilly \& Eckersall, 2014) and also plays a role in iron metabolism (Lovstad, 2006) (Table 1). It is classified as a minor APP in sheep and goats (Table 2). $\mathrm{Cp}$ is a ferroxidase and acts as an antioxidant that converts the toxic ferrous ion $\left(\mathrm{Fe}^{2+}\right)$ into the non-toxic ferric ion $\left(\mathrm{Fe}^{3+}\right)$ and thus protects the tissues from damaging effects of free radicals (Patel et al., 2002; Murata et al., 2004). Summarised data (Murata et al., 2004) show that Cp is synthesised primarily in the liver but other tissues can be involved including respiratory epithelium of the lung.

\section{Fibrinogen}

Fibrinogen $(\mathrm{Fb})$ is a soluble glycoprotein belonging to $\beta$-globulin fraction of the blood plasma. It is classified as a minor APP in sheep but moderate in goats (Table 2). The tissue injury is one of the primary stimulus responsible for activation of the coagulation cascade involving many and different types substances. $\mathrm{Fb}$ is a coagulation protein and its synthesis increased during the APR (Davalos \& Akassoglou, 2012). It is important to note that if intravascular coagulation occurs, $\mathrm{Fb}$ plasma concentration decreases. $\mathrm{Fb}$ is a substrate for fibrin formation and also serves as a matrix for migration of inflammation-related cells and healing of wounds (Raynes, 1994; Thomas, 2000; Murata et al., 2004). It binds specifically to the CD11/CD18 receptors on the migrated phagocytes surface and releases a cascade of intracellular signals that lead to increased degranulation, phagocytosis, antibody-dependent cellular cytotoxicity and delayed apoptosis (Rubel et al., 2001; Murata et al., 2004).

\section{Alfa-1 acid glycoprotein}

Alpha-1 acid glycoprotein (AGP) or orosomucoid is highly glycosylated protein synthesised mainly by liver but extrahepatic production (notably epithelial and endothelial cells) have also been confirmed (Fournier et al., 2000; Murata et al., 2004). AGP is considered as a moderate APP in small ruminants (Table 2). It has at least three important biological functions (Table 1). Like serum albumin, AGP is a binding protein in plasma (O'Reilly \& Eckersall, 2014). In physiological conditions, AGP is able to bind more than 300 different biologically active endogenous and exogenous substances such as heparin, histamine, serotonin, steroids, catecholamines and drugs (Fournier et al., 2000; Israili \& Dayton, 2001; Eckersall, 2008; Ceciliani et al., 2012). Other suggested AGP functions are the inhibition of neutrophil activation, phagocytosis, platelet activating factor, natural killer cell activity and also a role in T- and B-cell maturation which determines its anti-inflammatory and immunomodulatory activities (Okumura et al., 1985; Fournier et al., 2000; Israili \& Dayton, 2001; Murata et al., 2004; Eckersall, 2008). It exhibits a moderate response in 
most animals including small ruminants and is likely to be associated with chronic conditions (Tothova et al., 2014). AGP has a role in the innate defense and may act as a non-specific antimicrobial agent by binding directly with lipopolysaccharide and neutralising its toxicity (Moore et al., 1997; Murata et al., 2004; Raich, 2012).

\section{Hemopexin}

Hemopexin (Hpx) is a heme-binding plasma glycoprotein consisting of a single polypeptide chain which is synthesised by hepatocytes in response to IL-6 stimulation (Immenschuh et al., 1995). Heme (iron-protoporphyrin IX) is a component of haemoglobin, myoglobin and some enzymes such as cytochrome, heme peroxidase and others (Smith, 1999). It is released mainly after the destruction of red blood cells. The main function of Hpx is to bind free heme and to protect from oxidative stress, therefore, it acts as an antioxidant (Gutteridge, 1995). Together with Hp and transferrin, Hpx plays a role in the iron homeostasis (Delanghe \& Langlois, 2001). Other important role of $\mathrm{Hpx}$ is to bind nitric oxide (Shipulina et al., 1998) and carbon monoxide (Shaklai et al., 1981) and thus to neutralise their toxicity. Information concerning $\mathrm{Hpx}$ in small ruminants is limited but there are some data about its behaviour during protozoan diseases (Sousa Almeida et al., 2012).

\section{Alfa-1 antitrypsin}

Alpha-1 antitrypsin (AAT) is an APP belonging to serpins with a broad spectrum of antiprotease activity (Table 1). AAT is a serine protease inhibitor which protects tissues from neutrophil proteolytic enzymes (mainly elastase and proteinase) at the site of imflammation (Murata et al., 2004; Tothova et al., 2014).

\section{Lactoferrin}

Lactoferrin (LF) is a part of the innate immunity system and represents one of the first defense reactions against pathogens invading via mucosal tissues (Legnard et al., 2005). LF activities affect the growth and proliferation of infectious agents such as bacteria, protozoan, viruses and fungi (Ward et al., 2002). LF is presented in most mucosal secretions such as colostrum, milk, saliva, small intestine secretion, nasal secretion (Tothova et al., 2014). It is known that neutrophils are the main source of plasma LF (Iyer \& Lonnerdal, 1993). In healthy organisms the plasma LF concentration is low but during infection or other tissue injuries it rapidly increases due to inflammatory cells activation (Adlerova et al., 2008). For this reason several authors classify LF as an APP (Kanyshkova et al., 2001). LF plays an important role during infection by binding the iron in stable compound (Adlerova et al., 2008). The complex LF-Fe does not disintegrate even at low $\mathrm{pH}$, notably at the site of inflammation due to metabolic changes occurred by pathogen activities (Valenti \& Antonini, 2005). It expresses a bacteriostatic effect of LF that makes the iron unavailable from bacterial growth and proliferation (Tothova et al., 2014).

\section{Albumin}

Albumin (Alb) is the main member of negative APP in ruminants (Table 2). It is the most abundant protein in the blood of animals and humans, representing 35$50 \%$ of total protein. Alb is responsible for about $75 \%$ of the osmotic pressure of plasma and is the main source of amino acids that may be utilised for synthesis of positive APPs during APR (Ceron et al., 2005; Tothova et al., 2014). Furthermore, the initiation of APR triggers downregulation of Alb production (Gabay \& 
Kushner, 1999). Beyond its role as a reservoir for amino acids, Alb also serves as a carrier protein for many organic and inorganic biologically active substances such as thyroxin, estrogen, bilirubin, penicillin, cortisol, free fatty acids, calcium, magnesium, drugs and other which is possibly due to the variety of binding sites on the albumin molecule (Nicholson et al., 2000). The values of plasma Alb may be used as an indicator of nutritional status due to its relatively long half-life (Tothova et al., 2014).

\section{Transferrin}

Transferrin (TF) is a glycoprotein belonging to the family of metal binding transport proteins, synthesised in the liver and together with Alb described as a negative APP (Table 1). TF has a high capability to bind ferric ions in $\mathrm{pH}$ of 7.4 but reversibly when the acidity increase (Gomme \& McCann, 2005). According to Broch et al. (1987), Kaplan et al. (1991) and Gkouvatsos et al. (2012), iron chelation by transferrin has some important functions such as maintaining $\mathrm{Fe}^{3+}$ in soluble form under physiological conditions; supporting iron transport and cellular uptake; maintaining $\mathrm{Fe}^{3+}$ in a redox-inert state, preventing the generation of toxic free radicals and inhibition of the proliferation and growth of bacteria by limiting the access to iron.

\section{$C$-reactive protein}

C-reactive protein (CPR) is an APP belonging to the pentameric protein family (pentraxins) (Bottazzi et al., 1997). It performs several important functions such as the ability to activate the complement cascade by the classical pathway, modulation of activity of blood platelets, erythrocyte aggregation and opsonisation of necrotic tissues and cellular debris (Vojtic \&
Krajnc, 2000). Khan \& Khan (2010) also reported that CRP binds with highest affinity to phosphocholine residues in a calcium dependent manner, apoptotic cells, glycans, somatic components of bacteria, fungi and parasites. A number of physiological functions of CPR and its behaviour during various infectious and non-infectious diseases in sheep and goats are not fully elucidated. However, there are data showing that the CRP plasma levels are increased in the case of various types of pneumonia in sheep and goats (Haligur \& Ozmen, 2011).

\section{Lipopolysaccharide binding protein}

Lipopolysaccharide binding protein (LBP) is a serum glycoprotein belonging to a small family of lipid-binding proteins together with some other proteins (bactericidal permeability-increasing protein, phospholipid transfer protein, cholesteryl ester transfer protein) (Gustsmann et al., 2001). LBP is synthesised in the liver and intestinal epithelial cells (Ramadori et al., 1990; Vreugdenhil et al., 1999). It plays a key role of innate immune response against bacteria (Ceciliani et al., 2012). Lipopolysaccharide (LPS) molecules are components of external membrane of Gram negative bacteria (Gustsmann et al., 2001) and responsible for the biological toxicity (Raetz, 1990; Rietschel \& Brade, 1992). The biological actions of LPS are mediated by both LPS-binding proteins and LPS receptors (Fenton \& Golenbock, 1998). LBP binds and transfers a bacterial LPS to the CD14, CD11/18 receptors of antigen-presented cells (Fenton \& Golenbock, 1998) and granulocytes (Lamping et al., 1996). This leads to cellular activation resulting in the release of systemically active pro-inflammatory molecules, which in turn mediate systemic toxicity (Fenton \& Golenbock, 1998). Enhancement or 
inhibition of LPS-induced cellular activation depends on LBP concentration. Low LBP concentration performs a pro-inflammatory role (activation of mononuclear cells), whereas high concentration has an anti-inflammatory role by inhibition LPSinduced cellular stimulation (Lamping et al., 1996; Gustsmann et al., 2001; Ceciliani et al., 2012). LPB is able to bind not only with LPS but also with lipoteicholic acid, a major constituent of the cell wall of Gram-positive bacteria (Ceciliani et al., 2012).

\section{ASSESSMENT METHODS AND REFERENCE RANGES}

It is known that the plasma levels of APPs are low in the absence of the pathological process. However, there are number of sensitive methods developed for establishing their values both in patients and in healthy subjects which are presented in Table 3 .

Several studies have been conducted in goats and sheep which are designed to determine the reference ranges of APPs in healthy animals (Table 4). In this table are also mentioned some studies that have been conducted in sheep and goats in experimental settings but the data concerning the ranges of APPs values are obtained only from the healthy animals included in the control groups.

\section{CONCLUSION}

A wide range of investigations have been conducted to determine the usefulness of APPs in various diseases especially in cattle, but data concerning these reactants are still relatively under-utilised in sheep and goats. Overall, they are a useful indi-

Table 3. Assays for measuring APPs in small ruminants

\begin{tabular}{|c|c|c|}
\hline APPs & Measurement method & Reference \\
\hline Hp & $\begin{array}{l}\text { Colorimetric method based on the haemoglobin-binding } \\
\text { capacity and preservation of the peroxidase activity of the } \\
\text { bound haemoglobin at low } \mathrm{pH} \text { (Phase Haptoglobin Assay } \\
\text { kit, Tridelta, Ireland). }\end{array}$ & Eckersall (2006b) \\
\hline SAA & Solid phase sandwich ELISA (Tridelta, Ireland) & $\begin{array}{l}\text { Colom-Cadena et al. } \\
\text { (2014) }\end{array}$ \\
\hline $\mathrm{Cp}$ & $\begin{array}{l}\text { Colorimetric enzyme assay by p-phenylenediamine dihy- } \\
\text { drochloride oxidation measurement }\end{array}$ & Meling et al. (2012) \\
\hline $\mathrm{Fb}$ & $\begin{array}{l}\text { Heat precipitation method. } \\
\text { Nephelometric method. }\end{array}$ & $\begin{array}{l}\text { Ulutas \& Ozpinar (2006) } \\
\text { Fasulkov et al. (2014) }\end{array}$ \\
\hline CPR & $\begin{array}{l}\text { Turbidimetric immunoassay by liquid phase immunopre- } \\
\text { cipitation reaction with rabbit polyclonal antibodies } \\
\text { against human CRP (Protiline, BioMérieux) }\end{array}$ & Vojtic \& Krajnc (2000) \\
\hline ASG & $\begin{array}{l}\text { Precipitation method by perchloric acid and determination } \\
\text { using bicinchoninic acid protein assay reagent }\end{array}$ & $\begin{array}{l}\text { Eckersall et al. (1996) } \\
\text { Gonzalez et al. (2008) }\end{array}$ \\
\hline AGP & Radial immunodiffusion by kit (J-Path Inc. Tokyo, Japan). & Eckersall et al. (2007) \\
\hline LBP & $\begin{array}{l}\text { Commercial ELISA kits (Jiancheng Biology Co., Nanjing, } \\
\text { China) }\end{array}$ & Zhong et al. (2014) \\
\hline
\end{tabular}


Acute phase proteins in sheep and goats - function, reference ranges and assessment methods...

Table 4. APPs ranges in healthy small ruminants

\begin{tabular}{|c|c|c|}
\hline APPs, species & Normal range (examined) & Reference \\
\hline Hp, Sheep & $\begin{array}{l}0.16 \pm 0.13-0.19 \pm 0.10 \mathrm{~g} / \mathrm{L} \\
0.197 \pm 0.015 \mathrm{~g} / \mathrm{L} \\
0.99 \pm 0.12 \mathrm{~g} / \mathrm{L} \\
0.30 \pm 0.06 \mathrm{mg} / \mathrm{mL} \\
0.038-0.112 \mathrm{~g} / \mathrm{L} \\
0-1.0 \mathrm{mg} / \mathrm{dL} \\
0.06-0.12 \mathrm{~g} / \mathrm{L} \\
0.048 \pm 0.008 \mathrm{mg} / \mathrm{mL} \\
0.99( \pm 0.062)-0.122( \pm 0.101) \mathrm{g} / \mathrm{L} \\
0.215( \pm 0.068)-0.260( \pm 0.081) \mathrm{mg} / \mathrm{mL}\end{array}$ & $\begin{array}{l}\text { Ulutas \& Ozpinar (2006) } \\
\text { Aziz \& Taha (1997) } \\
\text { Eckersall et al. }(2007) \\
\text { Wells et al. }(2013) \\
\text { Zhong et al. }(2014) \\
\text { Jain } \text { et al. } \text { (2011) } \\
\text { Lepherd et al. }(2009) \\
\text { Gurdogan } \text { et al. }(2014) \\
\text { Nowroozi-Asl et al. }(2008) \\
\text { Pfeffer \& Rogers (1989) }\end{array}$ \\
\hline Hp, Goats & $\begin{array}{l}0.12-0.14 \mathrm{mg} / \mathrm{mL} \\
0.1 \mathrm{~g} / \mathrm{L} \\
3.05 \pm 1.08 \mathrm{~g} / \mathrm{L} \\
0-0.05 \mathrm{~g} / \mathrm{L} \\
0.39-1.26(0.784) \mathrm{mg} / \mathrm{dL} \\
41.6 \mathrm{mg} / \mathrm{L} \\
0.58 \mathrm{mg} / \mathrm{L} \\
0.056 \pm 0.009 \mathrm{mg} / \mathrm{L}\end{array}$ & $\begin{array}{l}\text { Ulutas et al. }(2008) \\
\text { Hashemnia et al. }(2011) \\
\text { Fasulkov et al. }(2014) \\
\text { Gonzalez et al. }(2008) \\
\text { Heller \& Johns }(2015) \\
\text { Gonzalez et al. }(2011) \\
\text { Rahman et al. }(2010) \\
\text { Balikci et al. }(2013)\end{array}$ \\
\hline SAA, sheep & $\begin{array}{l}2.67 \pm 0.23 \mathrm{mg} / \mathrm{L} \\
0.82 \pm 0.53 \mu \mathrm{g} / \mathrm{mL} \\
0.963-8.54 \mathrm{mg} / \mathrm{L} \\
0-2.0 \mu \mathrm{g} / \mathrm{mL} \\
5.62 \pm 0.84 \mu \mathrm{g} / \mathrm{mL}\end{array}$ & $\begin{array}{l}\text { Eckersall et al. (2007) } \\
\text { Wells et al. }(2013) \\
\text { Zhong et al. }(2014) \\
\text { Lepherd et al. }(2009) \\
\text { Gurdogan et al. }(2014) \\
\end{array}$ \\
\hline SAA, goats & $\begin{array}{l}4.20-12.65 \mu \mathrm{g} / \mathrm{mL} \\
6.1 \mu \mathrm{g} / \mathrm{mL} \\
1.69-11.94(4.88) \mathrm{mg} / \mathrm{L} \\
0.42-2.2(0.92) \mu \mathrm{g} / \mathrm{ML} \\
8.7 \mu \mathrm{g} / \mathrm{mL} \\
6.06 \pm 0.89 \mu \mathrm{g} / \mathrm{mL}\end{array}$ & $\begin{array}{l}\text { Ulutas et al. }(2008) \\
\text { Hashemnia et al. }(2011) \\
\text { Gonzalez et al. }(2008) \\
\text { Heller \& Johns }(2015) \\
\text { Rahman et al. }(2010) \\
\text { Balikci et al. }(2013)\end{array}$ \\
\hline AGP, sheep & $\begin{array}{l}2.14 \pm 0.24 \mathrm{~g} / \mathrm{L} \\
0.246-0.470 \mathrm{~g} / \mathrm{L}\end{array}$ & $\begin{array}{l}\text { Eckersall et al. (2007) } \\
\text { Zhong et al. (2014) }\end{array}$ \\
\hline AGP, goats & $4.6-40.5(18.43) \mathrm{mg} / \mathrm{dL}$ & Heller \& Johns (2015) \\
\hline LBP, sheep & $1.20-2.79 \mathrm{~g} / \mathrm{L}$ & Zhong et al. (2014) \\
\hline LBP, goats & $0-0.68(0.125) \mathrm{ng} / \mathrm{mL}$ & Heller Johns (2015) \\
\hline $\mathrm{Cp}$, sheep & $\begin{array}{l}11.8 \pm 2.3-13.5 \pm 1.8 \mathrm{mg} / \mathrm{dL} \\
0.030-0.039 \mathrm{~g} / \mathrm{dL}\end{array}$ & $\begin{array}{l}\text { Ulutas \& Ozpinar (2006) } \\
\text { Sousa Almeida et al. (2012) } \\
\end{array}$ \\
\hline $\mathrm{Cp}$, goats & $\begin{array}{l}4.97-11.85 \mathrm{mg} / \mathrm{dL} \\
1.1 \mathrm{mg} / \mathrm{L}\end{array}$ & $\begin{array}{l}\text { Ulutas et al. (2008) } \\
\text { Rahman et al. (2010) }\end{array}$ \\
\hline CRP, sheep & $\begin{array}{l}0.51 \pm 0.19-0.55 \pm 0.10 \mathrm{mg} / \mathrm{dL} \\
5.235 \pm 0.429-9.115 \pm 0.647 \mathrm{mg} / \mathrm{L}\end{array}$ & $\begin{array}{l}\text { Ulutas \& Ozpinar (2006) } \\
\text { Vojtic \& Krajnc (2000) }\end{array}$ \\
\hline $\mathrm{Fb}$, sheep & $\begin{array}{l}436.2 \pm 39.5-437.5 \pm 47.8 \mathrm{mg} / \mathrm{dL} \\
1.6-4.1 \mathrm{~g} / \mathrm{L}\end{array}$ & $\begin{array}{l}\text { Ulutas \& Ozpinar (2006) } \\
\text { Lepherd et al. (2009) }\end{array}$ \\
\hline $\mathrm{Fb}$, goats & $\begin{array}{l}3.2 \pm 0.69 \mathrm{~g} / \mathrm{L} \\
2-4(2) \mathrm{g} / \mathrm{L} \\
2.67 \mathrm{~g} / \mathrm{L}\end{array}$ & $\begin{array}{l}\text { Fasulkov et al. }(2014) \\
\text { Gonzalez et al. }(2008) \\
\text { Gonzalez et al. }(2011)\end{array}$ \\
\hline Hpx, sheep & $0.013-0.018 \mathrm{~g} / \mathrm{dl}$ & Sousa Almeida et al. (2012) \\
\hline ASG, goats & $\begin{array}{l}0.86-1.78(1.25) \mathrm{g} / \mathrm{L} \\
1.38 \mathrm{~g} / \mathrm{L}\end{array}$ & $\begin{array}{l}\text { Gonzalez et al. (2008) } \\
\text { Gonzalez et al. }(2011)\end{array}$ \\
\hline $\begin{array}{l}\text { TF, sheep } \\
\text { AAT, sheep }\end{array}$ & $\begin{array}{l}0.352-0.448 \mathrm{~g} / \mathrm{dL} \\
0.155-0.193 \mathrm{~g} / \mathrm{dL}\end{array}$ & $\begin{array}{l}\text { Sousa Almeida et al. (2012) } \\
\text { Sousa Almeida } \text { et al. }(2012)\end{array}$ \\
\hline
\end{tabular}


cator for detecting animals with subclinical infections, determining the prognosis of clinical infection, differentiation between viral and bacterial disease, treatment monitoring, vaccine effectiveness and stress conditions. It is known that the increased APPs concentration is not specifical for a particular disease but reflects the overall health of the animals. Based on these data it can be concluded that the knowledge of APPs could be useful for establishment of herd health in small ruminants.

\section{REFERENCES}

Adlerova, L., A. Bartoskova \& M. Faldyna, 2008. Lactoferrin: A review. Veterinarni Medicina, 53, 457-468.

Aziz, D. M. \& M. B Taha, 1997. Effect of dystocia on serum haptoglobin in Awassi ewes. Theriogenology, 48, 559-562.

Balikci, E., A. Yildiz \& F. Gurdogan, 2013. Selected acute phase proteins, oxidative stress biomarkers, and antioxidants in aborting and non-aborting goats infected with Border disease virus. Bulletin of the Veterinary Institute in Pulawy, 57, 371-374.

Baumann, H. \& J. Gauldie, 1994. The acute phase response. Immunology Today, 15, 74-80.

Bottazzi, B., V. Vouret-Craviari, A. Bastone, L. De Gioia, C. Matteucci, G. Peri, F. Spreafico, M. Pausa, C. D'Ettorre, E. Gianazza, A. Tagliabue, M. Salmona, F. Tedesco, M. Introna \& A. Mantovani, 1997. Multimer formation and ligand recognition by the long pentraxin PTX3. Similarities and differences with the short pentraxins C-reactive protein and serum amyloid P component. Journal of Biological Chemistry, 272, 32817-32823.

Brock, J. H., T. Mainou-Fowler \& S. J. McGregor, 1987. Transferrins and defence against infection. Annali dell'Istituto Superiore di Sanita, 23, 935-941.
Ceciliani, F., A. Giordano \& V. Spagnolo, 2002. The systemic reaction during inflammation: the acute-phase proteins. Protein and Peptide Letters, 9, 211-223.

Ceciliani, F., J. J. Ceron P. D. Eckersall \& H. Sauerwein, 2012. Acute phase proteins in ruminants. Journal of Proteomics, 75, 4207-4231.

Ceron, J. J., P. D. Eckersall \& A. MartinezSubiela, 2005. Acute phase proteins in dogs and cats: Current knowledge and future perspectives. Veterinary Clinical $\mathrm{Pa}$ thology, 34, 85-99.

Colom-Cadena, A., R. Velarde, J. Salinas, K. Borge, I. Garcia-Bocanegra, E. Serrano, D. Gasso, E. Bach, E. Casas-Diaz, J. LopezOlivera, S. Lavin, L. Len-Vizcaino \& G. Mentaberre, 2014. Management of a caseous lymphadenitis outbreak in a new Iberian ibex (Capra pyrenaica) stock reservoir. Acta Veterinaria Scandinavica, 56, $1-11$.

Cray, C., J. Zaias \& N. H. Altman, 2009. Acute phase response in animals: A review. Comparative Medicine, 59, 517-526.

D’Armiento, J., S. Dalal \& K. Shada, 1997. Tissue, temporal and inducible expression pattern of haptoglobin in mice. Gene, 195 , 19-27.

Davalos, D. \& K. Akassoglou, 2012. Fibrinogen as a key regulator of inflammation in disease. Seminars in Immunopathology, 34, 43-62.

Delanghe, J. \& M. Langlois, 2001. Hemopexin: A review of biological aspects and the role in laboratory medicine. Clinica Chimica Acta, 312, 13-23.

Eckersall, P. D., P. K. Saini \& C. McComb, 1996. The acute phase response of acid soluble glycoprotein, $\alpha_{1}$-acid glycoprotein, ceruloplasmin, haptoglobin and C-reactive protein, in the pig. Veterinary Immunology and Immunopathology, 51, 377-385.

Eckersall, P. D., 2006a. Measurement of acute phase proteins as biomarkers of disease in production animals. In: Proceedings of the $57^{\text {th }}$ Annual Meeting of the American College of Veterinary Pathologists and the 
Acute phase proteins in sheep and goats - function, reference ranges and assessment methods ...

$41^{\text {st }}$ Annual Meeting of the American Society for Veterinary Clinical Pathology, Tucson, Arizona, USA.

Eckersall, P. D., 2006b. Acute phase proteins: form, function and analysis. In: Proceedings of the $57^{\text {th }}$ Annual Meeting of the American College of Veterinary Pathologists and the $41^{\text {st }}$ Annual Meeting of the American Society for Veterinary Clinical Pathology, Tucson, Arizona, USA.

Eckersall, P. D., 2006c. Acute phase proteins as biomarkers of disease in companion and laboratory animals. In: Proceedings of the $57^{\text {th }}$ Annual Meeting of the American College of Veterinary Pathologists and the $41^{\text {st }}$ Annual Meeting of the American Society for Veterinary Clinical Pathology, Tucson, Arizona, pp 47-52.

Eckersall, P., F. Lawson, L. Bence, M. Waterston, T. Lang, W. Donachie \& M. Fontaine, 2007. Acute phase protein response in an experimental model of ovine caseous lymphadenitis. BMC Veterinary Research, 3, 1-6.

Eckersall, P. D., 2008. Proteins, proteomics, and the dysproteinemia. In: Clinical Biochemistry and Domestic animals, $6^{\text {th }}$ edn, eds Kaneko, J. J., J. W. Harvey \& M. L. Briss, San Diego, California, USA, pp. 117-155.

Eckersall, P. D. \& R. Bell, 2010. Acute phase proteins: Biomarkers of infection and inflammation in veterinary medicine. The Veterinary Journal, 185, 23-27.

El Ghmati, S. M., E. M. van Hoeyveld, J. G van Strijp, J. L. Ceuppens \& E. A. Stevens, 1996. Identification of haptoglobin as an alternative ligand for CD11B/ CD18. Journal of Immunology, 156, 2542-2552.

Fasulkov, I., M. Karadaev, N. Vasilev, V. Urumova \& T. Mircheva, 2014. Determination of plasma fibrinogen and haptoglobin, hematological and blood biochemical changes in Bulgarian local goats with experimentally induced Staphylococcus aureus mastitis. Turkish Journal of Veterinary and Animal Sciences 38, 439-444.
Fenton, M. \& D. Golenbock, 1998. LPSbinding proteins and receptors. Journal of Leukocyte Biology, 64, 25-32.

Fournier, T., N. Medjoubi-N \& D. Porquet, 2000. Alpha-1-acid glycoprotein. Biochimica et Biophysica Acta, 1482, 157-171.

Gabay, C. \& I. Kushner, 1999. Acute-phase proteins and other systemic responses to inflammation. New England Journal of Medicine, 340, 448-454.

Gkouvatsos, K., G. Papanikolaou \& K. Pantopoulos, 2012. Regulation of iron transport and the role of transferrin. Biochimica et Biophysica Acta, 1820, 188-202.

Gomme, P. T. \& K. B. McCann, 2005. Transferrin: Structure, functional and potential therapeutic action. Drug Discovery Today, 10, 267-273.

Gomez-Laguna, J. F. Salguero, F. Pallares, I. Rodríguez-Gómez, I. Barranco \& L. Carrasco, 2011. Acute phase proteins as biomarkers in animal health and welfare. In: Acute Phase Proteins as Early NonSpecific Biomarkers of Human and Veterinary Diseases, ed F. Veas, InTech, pp. 259-298.

Gonzalez, F. H., F. Tecles, S. MartinezSubiela, A. Tvarijonaviciute, L. Soler \& J. J. Ceron, 2008. Acute phase protein response in goats. Journal of Veterinary Diagnostic Investigation, 20, 580-584.

Gonzalez, F., F. Hernandez, J. Madrid, S. Martinez-Subiela, A. Tvarijonaviciute, J. Ceron \& F. Tecles, 2011. Acute phase proteins in experimentally induced pregnancy toxemia in goats. Journal of Veterinary Diagnostic Investigation, 23, 57-62.

Gruys, E., M. J. M. Toussaint, W. J. M. Landman, M. Tivapasi, R. Chamanza \& L. van Veen, 1999. Infection, inflammation and stress inhibit growth. Mechanisms and non-specific assessment of the processes by acute phase proteins. In: Production Diseases in Farm Animals: $10^{\text {th }}$ International Conference, ed T. Wensing, Wageningen Press, Wageningen, pp. 72-87.

Gruys, E., M. J. M. Toussaint, T. A. Niewold \& S. J. Koopmans, 2005. Acute phase re- 
action and acute phase proteins. Journal of Zhejiang University Science B, 6, 10451056.

Gurdogan, F., E. Balikci \& A. Yildiz, 2014. Some acute phase proteins, oxidative stress biomarkers and antioxidant enzyme activities in ewes with pregnancy toxemia. Iranian Journal of Veterinary Research, 15, 297-299.

Gutteridge J. M. C., 1995. Lipid peroxidation and antioxidants as biomarkers of tissue damage. Clinical Chemistry, 41, 18191828.

Gutsmann, T., M. Muller, R. MacKenzie, A. Wiese \& U. Seydel, 2001. Dual role of lipopolysaccharide (lps)-binding protein in neutralization of lps and enhancement of lps-induced activation of mononuclear cells. Infection and Immunity, 69, 6942-6950.

Haligur, M. \& O. Ozmen, 2011. Immunohistochemical detection of serum amyloid-a, serum amyloid-p, C-reactive protein, tumour necrosis factor- $\alpha$ and TNF- $\alpha$ receptor in sheep and goat pneumonias. Révue de Médecine Vétérinaire, 162, 475-481.

Hari-Dass, R., C. Shah, D. J. Meyer \& J. G. Raynes, 2005. Serum amyloid A protein binds to outer membrane protein $\mathrm{A}$ of Gram-negative bacteria. Journal of Biological Chemistry, 280, 18562-18567.

Hashemnia, M., A. Khodakaram-Tafti, S. Razavi \& S. Nazifi, 2011. Changing patterns of acute phase proteins and inflammatory mediators in experimental caprine coccidiosis. Korean Journal of Parasitology, 49, 213-219.

Heegaard, P. M., D. L. Godson, M. J. Toussaint, K. Tjonehoj, L. E. Larsen, B. Viuff $\&$ L. Ronsholt, 2000. The acute phase response of haptoglobin and serum amyloid A (SAA) in cattle undergoing experimental infection with bovine respiratory syncytial virus. Veterinary Immunology and Immunopathology, 77, 9-15.

Heller, M. \& J Johns, 2015. Acute phase proteins in healthy goats: Establishment of reference intervals. Journal of Veterinary Diagnostic Investigation, 27, 171-181.
Immenschuh, S., D. X. Song, H. Satoh \& U. Muller-Eberhard, 1995. The type II hemopexin interleukin-6 response element predominates the transcriptional regulation of the hemopexin acute phase responsiveness. Biochemical and Biophysical Research Communications, 207, 202-208.

Israili, Z. H. \& P. G. Dayton, 2001. Human alpha-1-glycoprotein and its interactions with drugs. Drug Metabolites Revue, 33, 161-235.

Iyer, S. \& B. Lonnerdal, 1993. Lactoferrin, lactoferrin receptors and iron metabolism. European Journal of Clinical Nutrition, 47, 232-241.

Jain, S., V. Gautam \& S. Naseem, 2011. Acute-phase proteins: A diagnostic tool. Journal of Pharmacy and Bioallied Science, 3, 118-127.

Janeway, C. A., P. Travers, M. Walport \& M J. Schlomschik, 2001. Immunology, $5^{\text {th }}$ edn, Taylor and Francis, London, pp. 732.

Kanyshkova, T. G., V. N. Buneva \& G. A Nevinsky, 2001. Lactoferrin and its biological functions. Biochemistry (Moscow), 66, 1-7 (RU).

Kaplan, J., I. Jordan \& A. Sturrock, 1991. Regulation of the transferrin-independent iron transport system in cultured cells. Journal of Biologycal Chemistry, 266 , 2997-3004.

Kato, G., 2009. Haptoglobin halts haemoglobin's havoc. Journal of Clinical Investigation, 119, 2140-2142.

Khan, F. \& M. Khan, 2010. Inflammation and acute phase response. International Journal of Applied Biology and Pharmaceutical Technology, 1, 312-321.

Lamping, N., A. Hoess, B. Yu, T. Park, S. Kirschning, D. Pfeil, D. Reuter, S. Wright, F. Herrmann \& R. Schumann, 1996. Effects of site-directed mutagenesis of basic residues (Arg 94, Lys 95, Lys 99) of lipopolysaccharide (LPS)-binding protein on binding and transfer of LPS and subsequent immune cell activation. Journal of Immunology, 157, 4648-4656. 
Acute phase proteins in sheep and goats - function, reference ranges and assessment methods ...

Legnard, D., E. Elass, M. Carpentier \& J. Mazurier, 2005. Lactoferrin: A modulator of immune and inflammatory response. Cellular and Molecular Life Sciences, 62, 2549-2559.

Lepherd, M. L., P. J. Canfield, G. B. Hunt \& K. L. Bosward, 2009. Haematological, biochemical and selected acute phase protein reference intervals for weaned female Merino lambs. Australian Veterinary Journal, 87, 5-11.

Linke, R. P., V. Bock, G. Valet \& G. Rothe, 1991. Inhibition of the oxidative burst response of $\mathrm{N}$-formyl peptide-stimulated neutrophils by serum amyloid-A protein. Biochemical and Biophysical Research Communication, 176, 1100-1105.

Lovstad, R. A., 2006. A kinetic study on the phenothiazine dependent oxidation of NADH by bovine ceruloplasmin. Biometals, 19, 1-5.

Mack, D. R., T. L. McDonald, M. A. Larson, S. Wei \& A. Weber, 2003. The conserved TFLK motif of mammary-associated serum amyloid $\mathrm{A}$ is responsible for up-regulation of intestinal MUC3 mucin expression in vitro, Pediatric Research, 53, 137-142.

McDonald, T. L., M. A. Larson, D. R. Mack \& A. Weber, 2001. Elevated extrahepatic expression and secretion of mammaryassociated serum amyloid A 3 (M-SAA3) into colostrum. Veterinary Immunology and Immunopathology, 83, 203-211.

Meling, S., K. Bardsen \& M. Ulvund, 2012. Presence of an acute phase response in sheep with clinical classical scrapie. $B M C$ Veterinary Research, 8, 1-11.

Moore, D. F., M. R. Rosenfeld, P. M. Gribbon, C. P. Winlove \& C. M. Tsai, 1997. Alpha-1-acid (AAG, orosomucoid) glycoprotein: Interaction with bacterial lipopolysaccharide and protection from sepsis. Inflammation, 21, 69-82.

Moshage, H , 1997. Cytokines and the hepatic acute phase response. Journal of Pathology, 181, 257-266.

Murata, H., N. Shimada \& M. Yoshioka, 2004. Current research on acute phase proteins in veterinary diagnosis: an overview. The Veterinary Journal, 168, 28-40.

Murtaugh, M. P., 1994. Porcine cytokines Veterinary Immunology and Immunopathology, 43, 37-44.

Nicholson, J. P., M. R. Wolmarans \& G. R. Park, 2000. The role of albumin in critical illness. British Journal of Anaesthesia, 85, 599-610.

Niewold, T. A., M. J. M. Toussaint \& E. Gruys, 2003. Monitoring health by acute phase proteins. In: Proceedings of the Fourth European Colloquium on Acute Phase Proteins, Segovia, Spain, pp. 57-67.

Nowroozi-Asl, A., S. Nazifi \& A. Bahari, 2008. Determination of serum haptoglobin reference value in clinically healthy Iranian fat-tailed sheep. Iranian Journal of Veterinary Research, 9, 171-173.

Okumura, Y., J. Kudo, T. Ikuta, S. Kurokawa, H. Ishibashi \& H. Okubo, 1985. Influence of acute-phase proteins on the activity of natural killer cells. Inflammation, 9, 211219.

O'Reilly, E. L. \& P. D. Eckersall, 2014. Acute phase proteins: a review of their function, behavior and measurement in chickens. World's Poultry Science Journal, 70, 27 43.

Pannen, B. H. J. \& J. L. Robotham, 1995. The acute-phase response. New Horizonts, 3 , 183-197.

Patel, B. N., R. J. Dunn, S. Y. Jeong, Q. Zhu, J. P. Julien \& S. David, 2002. Ceruloplasmin regulates iron levels in the CNS and prevents free radical injury. Journal of Neuroscience, 22, 6578-6586.

Petersen, H. H., J. P., Nielsen \& P. M. H. Heegaard, 2004. Application of acute phase protein measurements in veterinary clinical chemistry. Veterinary Research, 35, 163-187.

Pfeffer, A. \& K. M. Rogers, 1989. Acute phase response of sheep: Changes in the concentrations of ceruloplasmin, fibrinogen, haptoglobin and the major blood cell types as- 
sociated with pulmonary damage. Research in Veterinary Science, 46, 118-124.

Pyorala, S., 2000. Hirvonen's thesis on acute phase response in dairy cattle. $\mathrm{PhD}$ thesis. University of Helsinki, Helsinki, Finnland.

Raetz, C. R. H., 1990. Biochemistry of endotoxins. Annual Review of Biochemistry, 59, 129-170.

Rahman, M. M., C. Lecchi, C. Fraquelli, P. Sartorelli \& F. Ceciliani, 2010. Acute phase protein response in Alpine ibex with sarcoptic mange. Veterinary Parasitology, 168, 293-298.

Raich, E., 2012. Acute phase proteins in wild boar, Pyrenean chamois and ibex: Method validation and reference values. Tesi Doctoral, Universitat Autonoma de Barcelona, pp. 29-32.

Ramadori, G., K. Meyer zum Buschenfelde, P. Tobias, J. Mathison \& R. Ulevitch, 1990. Biosynthesis of lipopolysaccharide-binding protein in rabbit hepatocytes. Pathobiology, 58, 89-94.

Raynes, J. D., 1994. The acute phase response. Biochemical Society Transactions, 22, 69-74.

Rietschel, E. T. \& H. Brade, 1992. Bacterial endotoxins. Scientific American, 267, 26-31.

Rubel, C., G. C. Fernandez, G. Dran, M. B. Bompadre, M. A. Isturiz \& M. S. Palermo, 2001. Fibrinogen promotes neutrophil activation and delays apoptosis. Journal of Immunology, 166, 2002-2010.

Schaer, D. J., F. S. Roberti, G. Schoedon \& A. Schaffner, 2002. Induction of the CD163dependent haemoglobin uptake by macrophages as a novel anti-inflammatory action of glucocorticoids. British Journal of Haematology, 119, 239-243.

Schroedl, W., B. Fuerll, P. Reinhold, M. Krueger \& C. Schuett, 2001. A novel acute phase marker in cattle: lipopolysaccharide binding protein (LBP). Journal of Endotoxin Research, 7, 49-52.

Shainkin-Kestenbaum, R., G. Berlyne, S. Zimlichmam, H. R. Sorin, M. Nyska \& A. Danon, 1991. Acute phase protein, serum amyloid A, inhibits IL-1 and TNF induced fever and hypothalamic PGE2 in mice. Scandinavian Journal of Immunology, 34 179-183.

Shaklai, N., V. S. Sharma, U. Muller-Eberhard \& W. T. Morgan, 1981. The interaction of heme-hemopexin with CO. Journal of Biological Chemistry, 256, 1544-1548.

Shipulina, N., R. C. Hunt \& N. Shaklai, A. Smith, 1998. Coordination of nitric oxide by heme-hemopexin. Journal of Protein Chemistry, 17, 255-260.

Sipe, J. D., 1985. Acute phase proteins in chronic inflammation. In: The Acute Phase Response to Injury and Infection. ed A. Koj, Elsevier, Amsterdam, pp. 273-284.

Smith, D. J. \& D. Roberts, 1994. Effects of high volume and/or intense exercise on selected blood chemistry parameters. Clinical Biochemistry, 27, 435-440.

Smith A., 1999. Role of redox-reactive metals in the regulation of the metallothionein and heme oxygenase genes by heme and hemopexin. In: Iron Metabolism, eds G. C. Ferreira, J. J. G. Moura \& R. Franco, Wiley-VCH, Weinheim, pp. 65-92.

Sousa Almeida, K., A. Costa, P. Silva, J. Fagliari, R. Machado \& A. Nascimento, 2012. Acute phase proteins: A potential approach for diagnosing chronic infection by Trypanosoma vivax. Revista Brasileira de Parasitologia Veterinaria, 21, 97-100.

Thomas, J. S., 2000. Overview of plasma proteins. In: Schalm's Veterinary Hematology, $5^{\text {th }}$ edn, eds B. F. Feldman, J. G. Zinkl \& N. C. Jain, Lippincott Williams, Wilkins, Philadelphia, pp. 891-898.

Tirziu, E., 2009. Acute-phase proteins in immune response. Lucraris Stiintifice Medicina Veterinara, 42, 329-339.

Tothova, C., O. Nagy, H. Seidel \& G. Kováč, 2011. Acute phase proteins as markers of diseases in farm animals. In: Acute Phase Proteins as Early Non-Specific Biomarkers of Human and Veterinary Diseases, ed F. Veas, InTech, pp. 231-258.

Tothova, S., O. Nagy \& G. Kovac, 2014. Acute phase proteins and their use in the diag- 
Acute phase proteins in sheep and goats - function, reference ranges and assessment methods...

nosis of diseases in ruminants: a review. Veterinarni Medicina, 59, 163-180.

Uhlar, C. M. \& A. S. Whitehead, 1999. Serum amyloid A, the major vertebrate acutephase reactant. European Journal of Biochemistry, 265, 501-523.

Ulutas, P. \& A Ozpinar, 2006. Effect of Mannheimia (Pasteurella) haemolytica infection on acute-phase proteins and some mineral levels in colostrum-breast milkfed or colostrum-breast milk-deprived sheep. Veterinary Research Communications, 30, 485-495.

Ulutas, P., H. Voyvoda, B. Ulutas \& S. Aypak, 2008. Haptoglobin, serum amyloid- $\alpha$ and ceruloplasmin concentrations in goats with mixed helminth infection. Türkiye Parazitoloji Dergisi, 32, 229-233.

Ward, P. P., S. Uribe-Luna \& O. M. Conneely, 2002. Lactoferrin and host defense. Biochemistry and Cell Biology, 80, 95-102.

Valenti, P. \& G. Antonini, 2005. Lactoferrin: An important host defense against microbial and viral attack. Cellular and Molecular Life Sciences, 62, 2576-2587.

van Miert, A. S., 1995. Pro-inflammatory cytokines in a ruminant model: pathophysiological, pharmacological, and therapeutic aspects. Veterinary Quarterly 175, 41-50.

Vojtic, I. \& S. Krajnc, 2000. Determination of C-reactive protein by turbidimetric immunoassay (TIA) in sheep. Veterinarski Arhiv, 70, 151-157.

Vreugdenhil, A. C., M. A. Dentener, A. M. Snoek, J. W. Greve \& W. A. Buurman, 1999. Lipopolysaccharide binding protein and serum amyloid A secretion by human intestinal epithelial cells during the acute phase response. Journal of Immunology, 163, 2792-2798.

Wagener, F. A., A. Eggert, O. C. Boerman, W. J. Oyen, A. Verhofstad, N. G. Abraham, G. Adema, Y. Van Kooyk, T. De Witte \& C. G. Figdor, 2001. Heme is a potent inducer of inflammation in mice and is counteracted by heme oxygenase. Blood, 98, 1802-1811.
Wells, B., I. Innocent, P. Eckersall, E. McCulloch, A. Nisbet \& S. Burgess, 2013. Two major ruminant acute phase proteins, haptoglobin and serum amyloid $\mathrm{A}$, as serum biomarkers during active sheep scab infestation. Veterinary Research, 44, 103.

$\mathrm{Xu}$, L., R. Badolato, W. J. Murphy, D. L. Longo, M. Anver, S. Hale, J. J. Oppenheim \& J. M. Wang, 1995. A novel biologic function of serum amyloid A. Induction of $\mathrm{T}$ lymphocyte migration and adhesion. Journal of Immunology, 155, 1184 1190.

Yang, F., D. J. Haile, F. G. Berger, D. C. Herbert, E. Van Beveren \& A. J. Ghio, 2003. Haptoglobin reduces lung injury associated with exposure to blood. American Journal of Physiology - Lung and Cell Molecular Physiology, 284, 402-409.

Zhong, R., H. Yang Li, H. Sun \& D. Zhou, 2014. Effects of supplementation with dietary green tea polyphenols on parasite resistance and acute phase protein response to Haemonchus contortus infection in lambs. Veterinary Parasitology, 205, 199-207.

Paper received 09.06.2016; accepted for publication 30.09.2016

\section{Correspondence:}

Petar T. Iliev

Department of Veterinary Microbiology,

Infectious and Parasitic Diseases,

Faculty of Veterinary Medicine,

Trakia University

tel: +35942699587

e-mail: petyo_todorow@abv.bg 